\title{
Sexual transmission of human papillomaviruses in heterosexual and male homosexual couples, studied by DNA hybridisation
}

\author{
C WICKENDEN, ${ }^{\ddagger} \S$ N HANNA, $\dagger$ D TAYLOR-ROBINSON, $\ddagger$ J R W HARRIS, $\dagger$ \\ C BELLAMY,* P CARROLL,* A D B MALCOLM,§ D V COLEMAN*
}

From the *Department of Pathology, St Mary's Hospital Medical School, and the †Praed Street Clinic, St Mary's Hospital, London, the $\$$ Division of Sexually Transmitted Diseases, Clinical Research Centre, Harrow, Middlesex, and the §Department of Biochemistry, Charing Cross and Westminster Medical School, London

SUMMARY The prevalence of human papillomavirus (HPV) 6,11, 16, and 18 in 36 heterosexual couples and seven male homosexual couples with genital warts was investigated for evidence of sexual transmission of genital HPV. The prevalence of virus type and number of copies of viral genome equivalents/cell in the lesions were assessed, and the factors influencing transmission analysed. Our results show that HPV 6 and, to a lesser extent, HPV 11 were the types most readily transmitted, and that transmission appears to depend on the copy number and the duration and frequency of exposure.

The results of clinical studies of patients with genital warts have shown that these lesions are sexually transmissible.' To date, there have been no extensive studies of the transmission of different viral types present in genital warts using deoxyribonucleic acid (DNA) hybridisation techniques. We have developed a technique for assessing the type and quantity of human papillomavirus (HPV) DNA in cell samples and biopsy specimens, ${ }^{2}$ and have applied it to a study of the sexual transmissibility of HPV 6,11, 16, and $18,^{3-6}$ which commonly cause genital warts.

Campion et al reported that the female partners of men with genital warts have an increased risk of developing cervical intraepithelial neoplasia (CIN) and cited this evidence to support the hypothesis that HPV plays a part in cervical carcinogenesis. ${ }^{7}$ In this study we have also investigated that aspect of infection.

PATIENTS, MATERIALS AND METHODS

PATIENTS

Patients presenting with genital warts to the Praed Street clinic for sexually transmitted diseases were

Address for reprints: Dr D V Coleman, Department of Pathology, St Mary's Hospital Medical School, Praed Street, London W2INY I PG

Accepted for publication 11 June 1987 invited to bring their partners to the clinic within 28 days. Thirty six heterosexual and seven male homosexual couples were recruited into the study. The patients were questioned about the duration of their relationships.

\section{SPECIMENS}

We took biopsy specimens from exophytic warts and placed them in liquid nitrogen. From each female patient we took a cervical scrape, which was placed in phosphate buffered saline (PBS) for HPV DNA analysis as described previously, ${ }^{28}$ and a cervical scrape for Papanicolaou staining.

A total of 114 specimens were collected for DNA hybridisation studies from the heterosexual couples as follows: 36 cervical cell pellets and 55 penile, 15 vulval, three cervical, two perianal, and three pharyngeal wart biopsy specimens (table 1). Fifteen samples were collected for DNA analysis from the homosexual couples as follows: five penile, seven anal, and two perianal wart biopsy specimens and one anal scrape (table 2).

DNA was purified from the samples, immobilised on nylon filters, hybridised to labelled DNA from one of the four viral types, and then hybridised to a DNA probe for gamma actin. The type, prevalence, and number of copies of viral genome equivalents/cell were assessed. 
Table 1 Prevalence of human papillomavirus (HPV) types in 114 actin positive tissue samples from 37 heterosexual couples

\begin{tabular}{|c|c|c|c|c|c|c|c|}
\hline \multirow[b]{2}{*}{ Sample } & \multirow[b]{2}{*}{ No } & \multicolumn{6}{|c|}{ No (\%) of samples with HPV type: } \\
\hline & & Any type & 6 & 11 & 16 & 18 & > I type \\
\hline $\begin{array}{l}\text { Penile wart biopsy } \\
\text { Cervical scrape } \\
\text { Vulval wart biopsy } \\
\text { Cervical wart biopsy } \\
\text { Perianal wart biopsy } \\
\text { Pharyngeal wart biopsy }\end{array}$ & $\begin{array}{r}55 \\
36 \\
15 \\
3 \\
2 \\
3\end{array}$ & $\begin{array}{c}38(69) \\
5(14) \\
10(67) \\
3(100) \\
1(50) \\
0\end{array}$ & $\begin{array}{l}34(62) \\
3(8) \\
9(60) \\
1(33) \\
1(50) \\
0\end{array}$ & $\begin{array}{l}24(44) \\
2(6) \\
5(33) \\
1(33) \\
0 \\
0\end{array}$ & $\begin{array}{l}1(2) \\
0 \\
0 \\
1(33) \\
0 \\
0\end{array}$ & $\begin{array}{l}1(2) \\
0 \\
0 \\
2(67) \\
0 \\
0\end{array}$ & $\begin{array}{l}21(38) \\
1(3) \\
3(20) \\
2(67) \\
0 \\
0\end{array}$ \\
\hline
\end{tabular}

\section{DNA PROBES}

HPV 6 DNA was obtained as a $5 \cdot 3$ kilobase $(\mathrm{kb})$ restriction fragment cloned into the Bam $\mathrm{Hl}$ and Eco R1 sites of the pBR 322 plasmid. HPV 11 and 16 DNAs were obtained as full length $7.9 \mathrm{~kb}$ viral genomes, both cloned into the Bam $\mathrm{Hl}$ site of the $\mathrm{pBR}$ 322 plasmid. HPV 18 DNA was obtained as a full length $7.9 \mathrm{~kb}$ viral genome cloned into the Eco R1 site of the same plasmid..$^{3-6}$

To assess the human DNA content, each sample was hybridised to a probe for human gamma actin. The human genome contains 20 actin genes, ${ }^{9}$ which are all highly conserved and have a high degree of sequence homology. The probe used in this study was obtained as a full length cDNA of $1.6 \mathrm{~kb}^{10}$ cloned into the pCDV1 vector."

All recombinant plasmids were transferred into Escherichia coli HB 101 cells. Storage and culture of bacteria, plasmid amplification and isolation, and all molecular cloning procedures were performed as described previously. ${ }^{12}$

After plasmid preparation, the probes were separated from the vectors by digestion with the appropriate restriction enzymes and then electrophoresed into $1 \%$ low gelling temperature agarose. The gel was stained and photographed before excision of the band containing the probe, which was then melted and stored at $-20^{\circ} \mathrm{C}$ in $100 \mu \mathrm{l}$ aliquots until required.

\section{HYBRIDISATIONS}

Biopsy specimens and frozen cells were thawed and the biopsy specimens finely chopped before DNA extraction. DNA was extracted as described previously by overnight proteinase potassium and sodium dodecyl- suphate (K/SDS) digestion of the samples followed by phenol extraction and cold ethanol precipitation. ${ }^{8}$ Purified DNA was then spotted on a "Zetaprobe" nylon membrane filter, previously treated in a solution of $0.5 \%$ SDS, $0.1 \times$ sodium chloride and trisodium citrate (SSC), and $\times 5$ Denhardt's solution for one hour at $65^{\circ} \mathrm{C}$, using a 72 slot "Slot Blotter" suction manifold (Schliecher and Schuell Ltd) to give slots of DNA of equal area. Pure human DNA and pure linearised recombinant HPV DNA of an appropriate type were also spotted on the filter to provide a series of calibration standards. For each set of samples, four duplicate filters were prepared, one calibrated to each viral type.

Before initial hybridisation all filters were treated for one hour in the following solution at $65^{\circ} \mathrm{C}: 0 \cdot 1 \times$ SSC, $0.05 \%$ SDS, and $\times 5$ Denhardt's solution containing $0.1 \mathrm{mg} / \mathrm{ml}$ sonicated denatured salmon sperm DNA. The filters were then prehybridised overnight in the following solution at $42^{\circ} \mathrm{C}: 0.05 \%$ SDS; $0.08 \mathrm{~mol} / 1$ TRIS and hydrochloric acid ( $\mathrm{pH} \mathrm{7.8),}$ $0.004 \mathrm{~mol} / 1$ edetic acid (EDTA), $0.75 \mathrm{~mol} / 1$ sodium chloride, $0.1 \mathrm{mg} / \mathrm{ml}$ sonicated denatured salmon sperm DNA, and deionised formamide $50 \%$.

After prehybridisation the filters were hybridised to one of the DNA probes in $1 \mathrm{ml}$ of the prehybridisation mix containing at least $5 \mathrm{ng}$ probe DNA labelled with radiophosphorus $\left({ }^{32} \mathrm{P}\right)$ to a specific activity of not less than $10^{9}$ disintegrations per minute $(\mathrm{dpm}) / \mu \mathrm{g}$ by random oligomeric primer extension. ${ }^{13}$ Hybridisations were carried out for 36 hours at $42^{\circ} \mathrm{C}$, and the filters were subsequently subjected to three stringent washes at $65^{\circ} \mathrm{C}$ in a solution of $0.1 \times$ SSC and $0.1 \%$ SDS. After being washed the filters were autoradiographed on preflashed Fuji RX-100 $x$ ray film for five to 14 days

Table 2 Prevalence of human papillomavirus (HPV) types in 15 tissue samples from seven male homosexual couples

\begin{tabular}{|c|c|c|c|c|c|c|c|}
\hline \multirow[b]{2}{*}{ Sample } & \multirow[b]{2}{*}{ No } & \multicolumn{6}{|c|}{ No of samples with HPV type: } \\
\hline & & Any type & 6 & 11 & 16 & 18 & $>$ l type \\
\hline $\begin{array}{l}\text { Penile wart biopsy } \\
\text { Perianal wart biopsy } \\
\text { Anal wart biopsy } \\
\text { Anal scrape }\end{array}$ & $\begin{array}{l}5 \\
2 \\
7 \\
1\end{array}$ & $\begin{array}{l}5 \\
2 \\
7 \\
0\end{array}$ & $\begin{array}{l}3 \\
1 \\
5 \\
0\end{array}$ & $\begin{array}{l}2 \\
2 \\
5 \\
0\end{array}$ & $\begin{array}{l}0 \\
0 \\
1 \\
0\end{array}$ & $\begin{array}{l}0 \\
0 \\
0 \\
0\end{array}$ & $\begin{array}{l}2 \\
1 \\
4 \\
0\end{array}$ \\
\hline
\end{tabular}


Table 3 Distribution of human papillomavirus (HPV) types in 36 heterosexual couples

\begin{tabular}{|c|c|c|c|c|c|c|}
\hline \multirow{2}{*}{$\begin{array}{l}\text { Partners infected } \\
\text { (positive for probe) }\end{array}$} & \multicolumn{6}{|c|}{ No (\%) of couples with HPV DNA type: } \\
\hline & Any type & 6 & 11 & 16 & 18 & $>$ I type \\
\hline $\begin{array}{l}\text { Both } \\
\text { One } \\
\text { Neither }\end{array}$ & $\begin{array}{l}11(31) \\
14(39) \\
11(31)\end{array}$ & $\begin{array}{r}8(22) \\
13(36) \\
15(42)\end{array}$ & $\begin{array}{r}4(11) \\
12(33) \\
20(56)\end{array}$ & $\begin{array}{c}0 \\
2(6) \\
34(94)\end{array}$ & $\begin{array}{c}1(3) \\
1(3) \\
34(94)\end{array}$ & $\begin{array}{c}2(6) \\
14(39) \\
20(56)\end{array}$ \\
\hline
\end{tabular}

at $-70^{\circ} \mathrm{C}$. After autoradiography, the probe was washed off the samples three times for one hour each at $95^{\circ} \mathrm{C}$ cooling to $65^{\circ} \mathrm{C}$ in a solution of $0.5 \times \mathrm{SSC}$ and $0 \cdot 1 \%$ SDS. After re-exposure to $x$ ray film for a time comparable to the original exposure to check the efficiency of the washing procedure, the filters could be returned to the prehybridisation stage described above to permit subsequent rehybridisation to another probe.

Autoradiographs were scanned on a Joyce Loebl "Chromoscan 3" integrating densitometric scanner, the area under each absorbance peak being related to the intensity of the signal on the filter and hence to the mass of DNA in the sample. By relating the values obtained from the sample to those obtained from the calibration slots it was possible to obtain an accurate estimate of the relative quantities of viral and human DNA in each sample and thus to estimate the number of copies of viral genome equivalents/cell.

\section{Results}

PREVALENCE OF HPV TYPES IN BIOPSY SPECIMENS The results obtained with the DNA probes are presented, on a sample basis, in tables 1 and 2 . All samples contained sufficient DNA for analysis by hybridisation to the gamma actin probe. In heterosexual couples (table 1), HPV DNA was detected in $38(69 \%)$ of 55 samples from penile warts, five $(14 \%)$ of the 36 from cervical scrapes, $10(67 \%)$ of the 15 from vulval warts, and all (3/3) from cervical warts. HPV 6 and 11 were the most prevalent viral types, and HPV 16 and 18 were found only in penile and cervical warts. In the male homosexual couples (table 2), HPV DNA was detected in 14 of the 15 samples collected, and HPV 6 and 11 were again the most common viral types found.

Multiple samples were collected from a total of 24 heterosexual patients, the number of samples ranging from two to seven from each patient. Sixteen of these patients were positive for HPV DNA, and in $15(94 \%)$ the distribution of HPV types was homogeneous, the same type or types being found in all samples. Only one patient had different viral types in different samples.

\section{DISTRIBUTION OF HPV TYPES IN PARTNERS}

Of the 36 heterosexual couples, $25(69 \%)$ had both partners who were postive for HPV DNA, and 11 (31\%) yielded no viral DNA in either partner. HPV DNA was detected in one or both partners in the seven homosexual couples investigated. In tables 3 and 4 the couples are divided into three groups; those in which both partners were infected with the same type, those in which only one partner was infected with a particular type, and those with neither partner infected. Thus, as shown in table 3, HPV 6 was found in both partners in eight ( $22 \%$ ) of the 36 heterosexual couples studied, HPV 11 in both partners in four $(11 \%)$ couples, and HPV 18 in both partners of one couple only. Couples with the same multiple type infection were also rare; only two heterosexual couples had a shared mutiple infection. HPV 6 and 11 were also the most common types in couples with one partner positive for one specific type. Multiple infections were more common in this group, with $14(39 \%)$ people harbouring more than one viral type. A similar pattern was found in the homosexual couples (table 4).

\section{HPV DNA COPY NUMBERS}

We estimated numbers of copies of virus genome equivalents/cell for HPV 6 and 11 only. Copy numbers for HPV 6 ranged from 100 to 68000 (mean 9509), and HPV 11 copy numbers ranged from 100 to 16000 (mean 2388). The figure shows the mean (SD) copy numbers for HPV 6 in the heterosexual population. In

Table 4 Distribution of human papillomavirus (HPV) types in seven homosexual couples

\begin{tabular}{llllll}
\hline & \multicolumn{2}{l}{ No of couples with HPV DNA type: } & & \\
\cline { 2 - 6 } $\begin{array}{l}\text { Partners infected } \\
\text { (positive for probe) }\end{array}$ & Any type & 6 & 11 & 16 & 18 \\
\hline Both & 4 & 2 & 4 & 0 & 0 \\
One & 3 & 5 & 0 & 1 & 0 \\
Neither & 0 & 0 & 3 & 6 & 0 \\
\hline
\end{tabular}




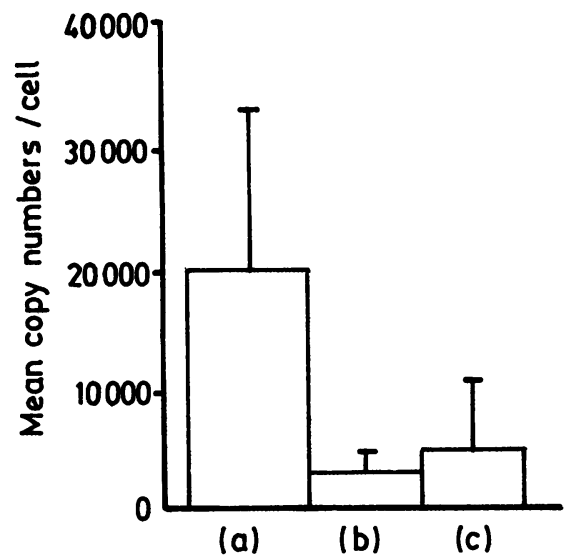

Figure Numbers of copies of human papillomavirus type 6 genome equivalents/cell in 21 infected heterosexual couples. Means of $(a)$ eight partners with higher copy numbers, (b) their eight partners, and (c) 13 partners from couples with only one infected partner. (Bars represent SD.)

couples with both partners infected with the same virus, one always had a much higher copy number than the other, the mean higher copy number for HPV 6 being 19683 and the mean lower copy number being 3077. This was an appreciable difference (as assessed by $t$ distribution analysis). When only one partner was infected the copy numbers were much lower, the mean copy number in these patients being 4987 .

The duration of relationships in the heterosexual couples ranged from six months to more than 10 years, the mean duration being 28 months. All had steady partners and only 12 had had casual sexual encounters in the previous 12 months. In contrast, the male homosexual couples had much shorter relationships, the maximum being two years, and had numerous casual sexual encounters in addition to their steady partners. The mean duration of relationship for all heterosexual couples who were both infected with HPV 6 was 22 months, and for those in which only one partner was infected was 17 months. Analysis of this result by $t$ distribution has shown that the five month difference between the mean duration of relationship

Table 5 Duration of relationships of 21 heterosexual couples infected with human papillomavirus type 6 (HPV 6) with one or both partners infected

\begin{tabular}{lll}
\hline $\begin{array}{l}\text { Duration of } \\
\text { relationship } \\
\text { (months) }\end{array}$ & \begin{tabular}{l} 
No of couples with \\
\cline { 2 - 3 } $\begin{array}{l}\text { One partner } \\
\text { infected }\end{array}$
\end{tabular} & $\begin{array}{l}\text { Both partners } \\
\text { infected }\end{array}$ \\
\hline Less than 6 & 1 & 0 \\
$6-12$ & 3 & 2 \\
$12-24$ & 6 & 3 \\
More than 24 & 3 & 3 \\
\hline
\end{tabular}

for the two populations is significant $(p<0 \cdot 1)$ at the $95 \%$ level. This would suggest that couples in which both partners were infected tended to have relationships of longer duration than did the couples in which only one partner was infected (table 5).

ASSOCIATION OF HPV WITH CER VICAL NEOPLASIA Cervical cytology, which has an accuracy of $89 \%$ in this laboratory, was undertaken for all the female partners of men in the heterosexual group. Examination using a speculum showed a normal cervix in each case, which was confirmed by cytology. In only one of these women was any abnormality noted; changes indicative of HPV infection were seen, but there was no evidence of malignancy. Her cytology sample was found to be positive for HPV 11.

\section{Discussion}

In the heterosexual couples, HPV 6 was the predominant viral type found, being present in $73 \%(8 / 11)$ of couples in which both partners were infected (coinfected) and in $93 \%(13 / 14)$ of couples with only one partner infected, thus being present in $84 \%(21 / 25)$ of the total infected population. These data show that HPV 6 is a ubiquitous infection in the heterosexual population suffering from genital warts, and on the basis that coinfection is a criterion for transmissibility, is the most readily transmitted of the viral types commonly found in genital papillomavirus infections.

A surprising result was the finding that HPV 11 appears to be the viral type most readily transmitted between homosexuals. Although HPV 6 was common, being found in all homosexual couples examined, it was only present in both partners of two couples. This may reflect a preference of HPV 11 for the anal mucosa. The samples from the 11 couples with both partners negative for HPV all contained adequate DNA for analysis. Our test was very stringent, and the samples in which a negative result was obtained may have been infected with a genital HPV type for which we did not probe, such as HPV 10 , or with a nongenital HPV type in the three patients with pharyngeal warts.

Analysis of the mean copy number of virus genome equivalents/cell in samples from the heterosexual couples provides a possible explanation for the transmissibility patterns of HPV 6 . The mean copy numbers of HPV 6 were much higher in couples with both partners infected than in those with one partner infected. It was also observed that when both partners were infected one had a much higher viral copy number than did the other. These data suggest, therefore, that the virus must replicate in the cell to a high level before it can be sexually transmitted to the other partner. 
The finding that coinfection appears to correlate with longer duration of the relationship indicates that, in addition to replication to higher levels before transmission, the recipient also must be subjected to repeated exposure to the virus before becoming infected. This is supported by the observation that those couples in which one or both were negative for HPV tended to have had shorter relationships.

The finding that HPV was absent from all but five of the cervical cell pellets that we examined, and that all but one of these cervices were cytologically normal irrespective of HPV infection, must call into question the suggestion that female partners of men with genital warts have an increased risk of $\mathrm{CIN},{ }^{7}$ although they are clearly at risk of developing genital warts themselves.

In summary, the data presented here suggest that HPV 6, the viral type most-often associated with exophytic warts, is a common and easily transmitted papillomavirus. This suggestion is supported by earlier work that has shown that genital warts are common, being found in $2 \%$ of a randomly selected population. ${ }^{14}$ and by other DNA hybridisation studies that show that HPV 6 is widely prevalent in such lesions. ${ }^{2}$ We have also shown, we think for the first time on a molecular biological basis, that the risk of becoming infected with these viruses appears to depend on viral copy numbers and the duration of exposure.

This study did not enable us to investigate the incubation period of genital papillomaviruses, but follow up of couples with only one infected partner should provide thîs information.

\section{References}

I Oriel JD. Natural history of genital warts. British Journal of
Venereal Disease 1971;47:1-13.

2 Wickenden C, Malcolm ADB, Smith C, Byrne M, Anderson MC, Coleman DV. Prevalence of HPV DNA and copy number in normal and abnormal cervices. J Pathol 1987;153:127-35.

3 Gissman L, zur Hausen H. Partial characterisation of viral DNA from human genital warts (condyloma acuminatum). Int $J$ Cancer 1980;25:605-9.

4 Gissman L, Diehl V, Schults-Coulon HJ, zur Hausen H. Molecular cloning and characterisation of human papillomavirus DNA derived from a laryngeal papilloma. $J$ Virol 1982;44:393-400.

5 Durst M, Gissman L, Ikenberg I, zur Hausen H. A papillomavirus DNA from a cervical carcinoma and its prevalence in cancer biopsy samples from different geographic regions. Proc Natl Acad Sci USA 1983;80:3812-5.

6 Boshart M, Gissman L, Ikenberg I, Kleinheinz A, Scheurlen W, Hausen H. A new type of papillomavirus DNA, its presence in genital cancer biopsies and in cell lines derived from cervical cancer. EMBO J 1984;3:1151-7.

7 Campion MJ, Singer A, Clarkson PK, McCance DJ. Increased risk of cervical neoplasia in consorts of men with penile condylomata acuminata. Lancet 1985; :943-6.

8 Wickenden C, Steele A, Malcolm ADB, Coleman DV. Screening for wart virus infection in normal and abnormal cervices by DNA hybridisation of cervical scrapes. Lancet 1985;i:65-7.

9 Humphries SE, Whitall PR, Minty A, Buckingham M, Williamson $R$. There are approximately 20 actin genes in the human genome. Nucleic Acids Res 1981;9:4895-908.

10 Gunning $\mathrm{P}$, Ponte $\mathrm{P}$, Okayama H, Engel J, Blau H, Keele L. Isolation and characterisation of full length cDNA clones for human and actin mRNAs: skeletal but not cytoplasmic actins have an amino-terminal cysteine that is subsequently removed. Mol Cell Biol 1983;3:787-95.

11 Okayama H, Berg P. A cDNA cloning vector that permits expression of cDNA inserts in mammalian cells. Mol Cell Biol 1983;1:286-9.

12 Maniatis T, Fritsch EF, Sambrook J. Molecular cloning: a laboratory manual. New York: Cold Spring Harbour Laboratory Press, 1982.

13 Feinberg AP, Vogelstein B. A technique for radiolabelling DNA restriction fragments to high specific activity. Anal Biochem 1983:132:6-13.

14 Miesels A, Morin C, Casas-Codero M. Human papillomavirus infection of the uterine cervix. Int J Gynecol Pathol 1982;1: 75-94. 